\title{
Paradigma Islam Rasional Harun Nasution: Membumikan Teologi Kerukunan'
}

\author{
Muhammad Irfan \\ Alumni Pascasarjana UIN Sunan Kalijaga Yogyakarta
}

\begin{abstract}
Abstraks
Harun Nasution (1919-1998) dikenal luas oleh kaum intelegensia Indonesia sebagai salah seorang ilmuan yang tekun mendalami berbagai bidang kajian keislaman, seperti ilmu kalam, falsafah, dan tasawuf. Salah satu dari kontribusinya adalah pengenalan pendekatan baru dalam studi Islam, yaitu. pendekatan filsafat dengan titik tekan pada rasio, "Rasionalisme" (akal) atau yang lebih dikenal dengan Islam Rasional. Perhatian Harun Nasution bukan saja terfokus pada bidang keilmuan Islam, tetapi juga terhadap permasalahan yang dihadapi umat Islam, khususnya di Indonesia. Di tengah maraknya isu-isu disharmonis, ketidakrukunan, kekerasan bahkan konflik, yang mengatasnamakan agama, maka pemikiran Islam rasional yang digagas oleh Harun Nasution merupakan solusi tawaran dalam memahami agama dalam rangka menwujudkan kerukunan umat beragama. Pemikran Islam rasional tidak hanya terbatas bagi umat Islam dalam mamahami agama secara rasional, tetapi dapat diterapkan pada agama lain dalam memahami agama secara rasional. Dengan pemahaman agama secara rasional, maka dapat membangun kerangka berpikir yang rasional dalam menyikapi persoalan umat manusia dan pemahaman agama secara rasional memberi kontribusi yang besar bagi terwujudnya kerukunan umat beragama.
\end{abstract}

\section{Keyword: Islam Rasional, Teologi kerukunan}

\section{A. Pengantar : Ruang Lingkup Teologi Kerukunan}

Menurut bahasa teologi ialah ilmu ketuhanan. Sedangkan secara terminologis, teologi merupakan ilmu yang membahas tentang Tuhan dan segala sesuatu yang terkait dengannya, baik itu menyangkut ekseistensi, sifat dan kekuasaannya, hubungan Tuhan dengan manusia ataupun manusia dengan Tuhan, juga termasuk di dalamnya hubungan vertikal sesama manusia yang dilandaskan

\footnotetext{
${ }^{1}$ Makalah ini diajukan untuk memenuhi tugas akhir semester III di PPS UIN Sunan Kalijaga Yogyakarta untuk tahun ajaran 2013-2014, pada mata kuliah "etika Islam untuk resolusi konfik dan perdamaian" dengan dosen pengampu: Dr. A. Singgih Basuki, M.A.
} 
pada nilai-nilai norma dan nilai kemanusiaan sesuai dengan perintah Tuhan (ajaran agama) kepada manusia. Hubungan antara sesama manusia yang melahirkan harmonitas dan kerukuan yang didasarkan pada konsep ajaran agama itulah yang dimaksud dengan teologi kerukunan. ${ }^{2}$

Agar ajaran teologi memiliki nilai fungsional bagi pengembangan dan peningkatan konsidi hidup masyarakat yang lebih baik—menyangkut bidang politik, ekonomi, kesehatan, ilmu pengetahuan, spiritual, sosial (termasuk bidang kerukunan) dan lainnya-maka pemikiran teologi harus dipandang sebagai sebuah produk ilmu pemikiran. Sehingga teologi dapat dikaji ulang sesuai dengan kebutuhan manusia di zamannya. Setidaknya ada tiga paradigm dalam memahami teologi, pertama, teologi sebagai kebijakan hidup, dalam arti kata bahwa teologi dipahami sebagai nilai, etos dan ajaran yang menuntut sesorang untuk berpikir dan berprilaku. Hal ini menuntut rasionalisasi atas doktrin-doktrin keagamaan secara proaktif, bukan pasif atapun raktif. Rasionalisasi teologi harus diarahkan untuk menjawab secara kreatif dan konstruktif untuk manusia dalam menjalankan hidup yang terus berkembang dan penuh tantangan; kedua, teologi sebagai metodologi. Dalam hal ini teologi merupakan suatu metode yang sejajar dengan metode keilmuan lainnya dalam mendekati, memahami dan mengkaji agama; ketiga, teologi sebagai ilmu pengetahuan. Oleh sebab itu teologi bersifat dimamis karena ia menyangkut produk pemikiran. ${ }^{3}$

Teologi kerukunan merukapan kontruksi teologi yang memiliki peranan yang signifikan dalah kehidupan umat beragama. Tegasnya, teologi kerukunan mengajak untuk meningkatkan keimanan kepada Tuhan dan membangun kesadaran untuk melakukan perbuatan baik kepada sesama manusia serta mendorong umat beragama hidup rukun bersama dengan kelompok agama lain.

Untuk itu, banyak tokoh-tokoh yang mencurahkan pemikiran dan aksinya untuk membangun kerukunan. Salah satuhnya ialah Harun Nasution. Harun

\footnotetext{
${ }^{2}$ Syahrin Harahap, Teologi Kerukunan, (Jakarta: Prenda Media Group, 2011), hlm. 15.

${ }^{3}$ Ngainun Naim, Teologi Kerukunan: Mencari Titik Temu Dalam Keberagamaan, (Yogyakarta: Teras, 2011), hlm. 7.
} 
Nasution adalah salah satu tokoh pembaharuan pemikiran Islam di Indonesia. Meskipun fokus kajiannya lebih banyak diarahkan kepada bidang-bidang ilmu, seperti: ilmu kalam, falsafah dan tasawuf, namun ternyata ia juga memiliki minat yang besar dalam mengkaji dan mempunyai andil dalam pengembangan pendidikan tinggi Islam khususnya di Indonesia. Selain itu juga, perhatiannya terhadap persoalan-persoalan umat beragama khususnya Indonesia juga tidak luput dari pemikirannya. Untuk itu, tulisan ini mencoba menggali dan menjabarkan kontribusi dari buah pemikiran Harun Nasution yang berkaitan dengan Teologi Kerukunan.

\section{B. Biografi singkat Harun Nasution}

Catatan tentang riwayat hidup Harun Nasution telah banyak ditulis dan diterbitkan baik melalui buku maupun majalah. Salah satunya dalam buku Refleksi Pembaharuan Pemikiran Islam 70 Tahun Harun Nasution telah panjang lebar dan spesifik mengurai riwayat hidup Harun Nasution. Namun demikian, Mengkaji epistemologinya pemikiran seorang tokoh tentunya tidak terlepas dari setting kontruksi sosio-cultural maupun sosio-politik, proses pendidikan yang ditempuh, dinamika masa dimana tokoh tersebut hidup. Ciri khas penelitian atau menelaah pemikiran tokoh adalah pencantuman biografi tokoh yang diteliti. Dengan mencamtumkan biografi seorang tokoh akan dapat mengetahui latarbelakang terbentuknya epistemologi pemikiran tokoh tersebut. ${ }^{4}$ Untuk itu, maka bagian ini mencoba menjelaskan dengan singkat riwayat hidup Harun Nasution.

Harun Nasution dilahirkan di Pematangsianar, daerah Tapanuli Selatan, Sumatra Utara, pada hari selasa, tanggal 25 September 1919. la adalah putra dari lima bersaudara. Ayahnya bernama Abdul Jabbar Ahmad, seorang ulama kelahiran Mandailing yang berkecukupan serta pernah menduduki jabatan sebagai Qadi, penghulu, Kepala Agama, Hakim Agama dan Imam Masjid di Kabupaten Simalungun. Sedangkan ibunya yang berasal dari Tanah Bato, yang merupakan putri

\footnotetext{
${ }^{4}$ Syahrin Harahap, Metodologi Studi Tokoh Pemikiran Islam, (Jakarta, Prenada Media Group: 2011), hlm. 30-34.
} 
JISA: Jurnal Ilmiah Sosiologi Agama

ulama asal mandaling dan masa gadisnya pernah bermukim di Makkah dan pandai bahasa Arab.

Harun Nasution mulai menempuh pendidikannya pada Sekolah Dasar milik Belanda, Hollandsch Inlandsh School (HIS), selama 7 tahun dan selesai tahun 1934 yang pada waktu itu ia sudah berumur 14 tahun. Kemudian beliau meneruskan studinya ke Moderne Islamietische Kweekschool ( MIK) di daerah Bukit Tinggi selama 3 tahun. Nasution walaupun semula enggan belajar di sekolah ini karena ingin masuk MULO, tapi akhirnya ia tertarik juga belajar di sekolah ini. Nasution mengaku tertarik mempelajari Islam, kerena Islam tampak sangat modern di tangan pengajar MIK. Di sinilah buat pertama kali Harun Nasution berhubungan dengan pemikiran moderen Islam, seperti yang dikembangkan oleh sejumlah sarjana Islam yang terkemuka seperti Hamka, Zainal Abidin, dan Jamil Jambek.

Setelah selesai dari sekolah MIK, orang tuanya menginginkan untuk melanjutkan studi ke Mekkah. Namun Harun memilih melanjutkan studinya ke Mesir di universitas al-Azhar, Kairo. Di Universitas al-Azhar beliau mengambil fakultas ushuluddin. Menjelang akhir studinya di Universitas al-Azhar, beliau memutuskan untuk masuk ke Universitas Amerika yang ada di Kota Kairo. Pada saat menjalankan studinya di Universitas Amerika itu, meletus perang dunia yang menjadikan hubungan Indonesia-Mesir terputus akibat peralihan penjajahan ke tangan Jepang. Akibatnya studinya di Universitas Amerika terbengkalai, dan di Universitas al-Azhar harus di tinggalkannya.

Pada tahun 1962, Harun Nasution mendapat tawaran dari HM Rasyidi untuk belajar di Institute of Islamic Studies McGill-Kanada. Di Universitas inilah beliau merasa puas belajar dan mengkaji tentang Islam. Hal yang berbeda yang ia dapat dari Universitas al-Azhar.

“Aku pergi ke McGill pada tanggal 20 September 1962. Di situlah aku betul-betul puas belajar Islam. Aku mendapat beasiswa selama beberapa tahun. Di sana juga aku memperoleh pandangan Islam yang luas. Bukan Islam seperti diajarkan di alAzhar Mesir. Di McGill aku punya kesempatan. Baik secara ekonomi maupun waktu. Aku membeli buku-buku modern, karangan orang Pakistan atau karya 
orientalis. Baik dalam bahasa Inggris, Prancis atau Belanda. Di sana liberal. Bebas. Jadi mudah mencarinya." 5

Setelah menyelesaikan studinya di Universitas McGill, beliau mendapatkan tawaran kerja dari IAIN dan UI di Jakarta. Namun beliau memilih IAIN Syarif Hidayatullah-Jakarta sebagai tempat ia mengabdikan diri sebagai dosen pada tahun 1969. Harun Nasution mencurahkan perhatian dan pemikirannya pada pengembangan pemikiran Islam melalui institusi pendidikan yaitu IAIN. Harun Nasution juga pernah menjabat sebagai Rektor IAIN Jakarta atas penunjukan Menteri Agama saat itu untuk mengantikan rektor lama, yaitu Thaha Yahya kerena sakit dan terserang lumpuh. Melalui jabatannya sebagai rektor, maka langkah pertama yang dilakukan beliau adalah mengubah kurikulum. Walaupun langkah tersebut mendapat pertentangan, namun akhirnya idenya mengadakan pembaharuan kurikulum terlaksana setelah berdiskusi dengan beberapa orang rektor sebelumnya.

Sebagai seorang intelektual, Harun Nasution telah melahirkan karya-karya berupa tulisan ilmiah. Karya-karyanya ini sering menjadi rujukan di kalangan akademisi Indonesia dalam konteks studi keislaman. Diantara karya-karyanya yang publikasikan adalah;

- Teologi Islam Aliran-aliran Sejarah Analisa Perbandingan (1972)

- Falsafat Agama (1973)

- Falsafat dan Mistisisme Dalam Islam (1973)

- Islam Ditindjau dari Berbagai Aspek, terdiri dari 2 Jilid

- Pembaharuan dalam Islam: Sejarah Pemikiran dan Gerakan (1975)

- Akal dan Wahyu dalam Islam (1982)

- Islam Rasional (1995). ${ }^{6}$

\footnotetext{
${ }^{5}$ Tim Panitia Penerbitan Buku dan Seminar 70 Tahun Harun Nasution, Refleksi Pembaharuan Pemikiran Islam 70 Tahun Harun Nasution, Lembaga Studi Agama dan Filsafat, Jakarta: 1989), hal. 34.

${ }^{6}$ Ariendonika, Sketsa Sosial Intelektual Harun Nasution, dalam Nurcholish Madjid, dkk, Teologi Islam Rasional: Apresiasi Terhadap Wacana dan Proksis Harun Nasution, (Ciputat Press, Jakarta: 2005), hal. 18.
} 
Harun Nasution adalah salah seorang tokoh pembaharuan Islam yang paling berpengaruh di lingkungan Islam terpelajar Indonesia. Oleh banyak kalangan, sosok Harun Nasution lebih dikenal sebagai seorang intelektual Muslim yang liberal. Ia banyak menawarkan cara pandang yang rasional, terbuka dan ilmiah terhadap kajian-kajian keislaman, seperti yang ia tuangkan dalam beberapa karyanya yang banyak dikonsumsi kalangan IAIN. Dalam kerangka liberal seperti itulah, Harun Nasution mengembangkan tradisi studi-studi Islam, khususnya di IAIN Syarif Hidayatullah Jakarta, yang lebih menekankan nilai-nilai akademis dan pendekatan rasional.

\section{Epistemologi Pemikiran Islam Harun Nasution}

Untuk menarik relevansi antara pemikiran Harun Nasution dengan teologi kerukunan, maka perlu terlebih memahami, membongkar serta mengkaji lebih mendalam struktur fundamental pemikirannya. Namun, sebelum masuk ke dalam struktur dasar pemikiran Islam Harun Nasution, perlu kiranya dijabarkan beberapa keprihatinan (kegelisahan akademik) Harun Nasution. Hal ini perlu dijelaskan karena setiap pemikiran selalu lahir dari respon atas keadaan di zaman dimana tokoh tersebut hidup. Keadaan zaman yang dipandangnya sebagai sesuatu yang "salah" dan pemikiran dari seorang tokoh merupakan gambaran jawaban dan tawaran solusi untuk mengatasi keadaan atau permasalahan agar lebih baik ke depannya.

\section{Beberapa kegelisahan Akademik}

Ada beberapa catat yang menjadi titik keprihatinan (kegelisaan akademik) Harun Nasution dalam melihat kondisi di dunia Islam. Diantaranya yang dapat dijabarkan ialah:

\section{Kemunduran Dunia Islam}

Salah satu kegelisahan akademik Harun nasution ialah keprihatinannya terhadap kemunduran umat Islam. Menurut Harun Nasution, Sebagaimana dalam kata pengantar untuk buku "Islam Rasional", bahwa kemunduran di dunia Islam akibat melemahnya penalaran secara rasional terhadap al-Qur'an dan Hadits di abad 
pertengahan. Dalam catatan sejarah, pada masa Islam klasik (650-1250 M) pemikiran rasional dalam di dunia Islam sangat berkembang pesat sehingga pada umat Islam mengalami kemajuan dalam berbagai bidang-seperti: sains, politik, ilmu pengetahuan, budaya, ekonomi. Hal ini didasari oleh tingginya kedudukan akal untuk memahami isi kandungan al-Qur'an dan Hadits. Rasionalitas pada masa klasik memang di pengaruhi oleh persepsi pemikiran dari Yunani. Bedanya, rasionalitas pemikiran Yunani sangat bebas tanpa terikat oleh ajaran agama, sedangkan rasionalitas dalam Islam tumbuh dan berkembang dalam bingkai ajaran agama Islam. Dengan demikian, ilmu-ilmu agama, seperti: tafsir, hadits, aqidah, ibadah, muamalah, tasawuf, pemikiran filsafat serta penemuan-penemuan ulama sains tidak bertentangan dengan ajaran agama Islam yaitu al-Qur'an dan Hadits.

Namun di abad pertengahan perkembangan pemikiran rasional semakin menurun, bahkan tergantikan oleh pemikiran tradisional. Pemikiran tradisional pada abad ini ditandai pada sikap peniruan (taqliq) terhadap hasil ijtihad ulama zaman klasik. Sikap peniruan ini terkadang dikultuskan (disucikan) sehingga sesuatu yang berlainan dengan pendapat ulama klasik merupakan tindakan penyimpangan.

\section{Paradigma Dogmatisme pemikiran Islam}

Dalam pemikiran Islam tradisional, peranan akal tidak begitu menentukan dalam memahami isi kandungan al-Qur'an dan Hadits. Seperti yang telah diterangkan di atas, pemikiran tradisional bukan saja terikat pada al-Qur'an dan Hadits secara tekstual, tetapi juga ajaran-ajaran hasil ijtihad ulama zaman Islam klasik. Akibatnya, lahir pemikiran Islam yang dogmatis-statis, rigit, taqliq (peniruan), sempit dan sebagainya terhadap al-Qur'an dan Hadits. Hal ini disebabkan oleh kungkungan logosenterisme7 pemikiran Islam dengan kecenderungan memebeda-

${ }^{7}$ Logosentrisme berasal dari kata "logos" yang berarti fondasi atau landasan. Logosentrisme sendiri mempunyai arti semua yang memiliki landasan dan fondasi. Secara harfiah logosentrisme berarti "keterpusatan pada logos". Logosentrisme terbentuk dari ilmu metafisika yang dipenuhi dengan impian dan nostalgia akan kebenaran, "logos" yang ilahiah dan transenden. Derrida logosentrisme adalah sistem metafisik yang membenarkan keadaan logos dan juga kebenaran transendental yang terjadi di dunia fenomenal. Pengunduran bahasa oleh logosentrisme dilakukakn dengan cara yang sistematis melalui metafisika yang lebih memprioritaskan kesatuan daripada keragaman, mengada daripada menjadi, ketetapan dari pada perubahandan kemutlakan dari pada relativitas. Logosentrisme adalah paham yang berasumsi bahwa sesuatu yang bersifat "penanda" (dalam istilah Derrida "bekas" atau "jejak") adalah 
bedakan, mensistematisasikan, mengolong-golongkan dan mengkotak-kotakkan objek kajian. Keadaan ini diperburuk dengan kecenderungan klaim-klaim kebenaran (Truth claim) terhadap penafsiran ajaran Islam diantara kelompok-kelompok muslim sendiri. Klaim kebenaran pemikiran dan penafsiran ajaran keislaman telah mendorong kepada kecenderungan stagnansi pemikiran Islam serta-secara sadar atau tidak sadar - telah mendorong konflik-konflik ideologis antar umat Islam dan bahkan antar penganut agama lain.

\section{Tantangan Global}

Arus globalisasi yang datang dengan cepat telah mengaburkan sekat-sekat antar individu, kelompok, bangsa. Hal ini disebabkan oleh perkembangan ilmu pengetahuan sains dan teknologi yang semakin canggih. Keadaan inipun memunculkan persoalan yang kompleks bagi kehidupan manusia, baik dari segi budaya, persoalan migrasi, hubungan antar agama, gender, HAM dan lain sebagainya. Era globalisasi yang datang dengan perubahan yang cukup fundamental mau tidak mau menuntut perubahan dalam segala bidang tanpa terkecuali pemikiran dan pendidikan keislaman, karena tanpa perubahan umat Islam akan menjadi penonton dan konsumtif terhadap perubahan tersebut.

Arus globalisasi telah merubah wajah dunia menjadi zaman modern. Mengahadapi era globalisasi (modernitas) tersebut, dunia Islam dinilai "gagap" dalam upaya menrespon dan menjawab persoalan globalisasi tersebut. Dampaknya, terjadi kemunduran di dunia Islam akibat ketertutupan pemikiran Islamsebagaimana yang dijelaskan di atas_dan bahkan cenderung "menutup diri", menyalahkan, serta menilai perubahan globalisasi merupakan nilai-nilai yang tidak

lebih awal daripada "petanda", dan tidak ada "petanda yang trandental". Konsepsi logosentris sangat berhubungan dengan pemikiran filsafat tradisional yang mengutamakan subjek sebagai asal realitas atau paling tidak memahami realitas secara rasional: artinya subjek yang menciptakan realitas_-baik mengenal maupun memahaminya-kemudian menyusun kembali secara rasional. Sikap mengutamakan subjek inilah yang dikritik dan ditolak oleh Derrida, baginya manusia (subjek) sebagai pemikir atau penulis sama sekali tidak bertindak secara bebas karena sangat tergantung pada teks atau suatu keseluruhan teks yang saling berkaitan dan mempengaruhi atau pada episteme dan wacana tertentu. Artinya manusia tidak mengungkapkan diri atau tidak dapat berpikir kecuali melalui bahasa, tradisi, kebahasaan dan tradisi teks tertentu.

Penggunaan Istilah logosentrisme ini di kemukakan oleh Jacques Derrida (1930-2004). Derrida adalah seorang Derrida adalah seorang filsuf Prancis, yang dianggap sebagai tokoh penting poststrukturalis-posmodernis. Lihat Muhammad Al-Fayyadl, Derrida, (Yogyakarta, LKis: 2005), hal. 73. 
sesuai dengan ajaran Islam maka tidak perlu untuk disikapi. Pergumulan antara Islam dan modernitas merupakan salah satu agenda permasalahan yang dihadapi oleh kaum Muslim saat ini. Terlebih lagi, sampai sekarang belum ada suatu pembahasan yang tuntas, baik dalam bentuk solusi maupun antisipasi, mengenai persoalan kaitan antara Islam dan modernitas.

Untuk kaitannya dengan Islam di Indonesia, persolan kemunduran di dunia Islam, dogmatism pemikiran, dan "gagapnya" menjawab dan merspon era globalisasi juga dirasakan di Indonesia. Di awal tahun 1970-1980an kajian pemikiran Islam di Indonesia masih banyak didominasi oleh paradigma dogmatisme pemikiran Islam yang kental. Sehingga umat Islam di Indonesia juga tidak bisa merespon dan menjawab arus modernisasi atas perubahan sosial, kultur, politik, dan keagamaan pada era global. Hal lain juga memunculkan klaim-klaim kebenaran penafsiran keislaman dari berbagai kelompok konservatif dan modern. Mendorong konflikkonflik ideologis antar umat Islam dan bahkan antar penganut agama lain juga kerap kali terjadi di Indonesia.

\section{Pemikiran Islam Rasional Harun Nasution}

Harun Nasution merupakan salah satu tokoh pemikir dan pembaharu Islam. Jika di Mesir lahir tokoh-tokoh pembaharuan seperti Al-Thahthawi, Muhammad Abduh, dan Jalaluddin Al-Afghani; di Turki: Mehmet Sedik Rifat, Nemik Kamal dan Zia Gokalp; di India: Ahmed Khan, Ameer Ali, dan Muhammad Iqbal, di Prancis: Mohammed Arkoun serta beberapa tokoh di beberapa negara lainnya, maka dapat dikatakan—untuk tidak berlebihan—bahwa Harun Nasution merupakan salah satu tokoh Pembaharuan Islam di Indonesia.

Konstruksi keilmuan (kerangka keilmuan) yang dibangun oleh tokoh-tokoh pembaharuan tersebut, termasuk Harun Nasution pada dasarnya sama yaitu perubahan paradigma Islam tradisionalis menuju paradigma Islam rasionalis, dengan menawarkan prinsip-prinsip rasional atau rasionalitas (akal) yang telah diuji dalam sejarah pemikiran Islam abad klasik. Meskipun “jargon-jargon” yang digunakankan 
untuk menggambarkan pembaharuan pemikiran Islam berbeda-beda misalkan seperti Modernisasi Islam, kontektualisasi Islam, dan lainnya, sementara Harun Nasution menggunakan istilah "Islam Rasional", 8 namun ide pembaharuan tersebut mengarah pada tujuan yang sama, yaitu perlunya mengkaji kembali ajaran Islam dengan menggunakan nalar rasional yang Islamis agar umat Islam mampu menjawab dan merespon perubahan globalisasi dan mampu mengerjar ketertinggalan.

Ada tiga prinsip dasar (basic philosofhy) yang menjadi model pemikiran Harun nasution, yaitu

1) Ide tentang kemajuan (idea of progress), ini merupakan kebalikan dari pandangan kejumudan/ statisnya pemikiran tentang Islam. Salah satu asumsi metafisika Harun Nasution adalah perubahan (being as process-being as progress). Oleh sebab itu, prinsip dasar pemikiran harus mengarah kepada ide kemajuan, karena dinamika pengetahuan selalu berkembang sesuai dengan perubahan zaman.

2) Koeksistensi antara wilayah absolut-tektual (qath'i) dan relativif-kontekstual (zhanni) sebagai perkembangan ilmu pengetahuan dalam Islam. Kategori qath'l (absolut) dan zhanni (relatif) bermula dari ushul figh. Harun Nasution mengutip dan kemudian menambahkan muatannya dengan unsur-unsur filosofis. Namun, Harun Nasution tidak selamanya menggunakan istilah ini. Menurut Dawam Raharjo, di awal karier intelektualnya, frekuensi Harun Nasution menggunakan istilah ini mulai jarang dan lebih banyak menggunakan istilah absolut dan relatif.

3) Perlawanan entitas secara oposisi biner antara rasional dan tradisional. ${ }^{9}$ Menurut Harun kalau ingin merubah masa depan maka yang di format ulang adalah cara berpikirnya. Metode berpikir rasional menyangkut cara kerja epistemology. Rasional yang dimaksudkan Harun adalah rasional ilmiah bukan rasional dalam pengertian “masuk akal”. Rasional, rasionalisme, rasionalis bukan semata percaya pada rasio saja, tetapi harus mengutamakan sumber pokok ajaran Islam

\footnotetext{
${ }^{8}$ Harun Nasution, Akal dan Wahyu dalam Islam, (Jakarta: UI Press, 1986), hlm.52.

${ }^{9}$ Nurisman, Pemikiran Filsafat Islam Harun Nasution; Pengembangan Pemikiran Islam di Indonesia, (Teras, Yogyakarta: 2005), hal. 172
} 
yaitu wahyu al-Qur'an dan hadits. Pemikiran tradisional, adalah model berpikir Indonesia yang dikontruksi oleh model berpikir dinamisme Indonesia prasejarah. Menurut Harun Hasution pemikiran tradisional adalah pemikiran yang di dalamnya akal mempunyai kedudukan yang rendah. Sedangkan rasional adalah sebaliknya. ${ }^{10}$

Menurut Harun Nasution, orang/ pihak yang pro terhadap kebebarasan berpikir disebut rasional, sedangkan yang pro pada tekstual baik wahyu maupun hadits disebut tradisional. Lebih lanjut Harun nasution menegaskan bahwa pro kepada akal tidak termasuk pemikir free thinkers, seperti Ibn al-Rawandi dan al-Razi. Dalam Islam, pemakaian akal tidak diberi kebebasan mutlak tetapi tidak pula diikat secara ketat sehingga menghambat pemikiran.

Rasionalisme dalam bentuknya ialah kontektual bukan universal. Apa yang disebut rasional dalam suatu system bisa jadi tidak rasional dalam system yang lain. Karena rasional bukan hanya logis sebagai suatu metodi pemikiran tetapi merupakan komitmen atau tujuan suatu system. Pada masyarakat juga terdapat pemikiran rasional sebagaimana masyarakat modern, tetapi bedanya pada kadar dan pelaksanaan untuk tujuannya. Wiratmo soekita mengatakan, kategori tradisional identik dengan sesuatu yang berasal dari nenek moyang, sedangkan modern sesuatu yang baru yang merupakan kategori yang dibuat oleh ahli-ahli psikologi Barat. Simuh melihat tradisional adalah ajaran tasawuf yang antara lain di campuri takhayul, bid'ah dah khurafat, sedangkan rasional adalah pemahaman kegamaan yang baru seperti yang ditawarkan oleh Muhammadiyah. ${ }^{11}$

Pemikiran rasional yang dimaksud oleh Harun Nasution adalah rasional ilmiah yang agamis. Karena bersifat ilmiah maka ia bersifat relatif. Arti rasional disini berarti mengikuti perkembangan ilmu pengetahuan. Jika rasional telah menemukan kebenaran baru, maka rasional itu akan menjadi tradisional, sebaliknya penemuan baru itulah yang disebut rasional. Dalam hal ini rasional berdekatan dengan pengertian modern.

\footnotetext{
Nurisman, Pemikiran Filsa fat ..., hlm. 224

${ }^{11}$ Nurisman, Pemikiran Filsafat..., hlm. 231.
} 
Untuk membangun kerangka rasionalitas, Harun nasution menjelaskan bahwa terdapat dua teori mengenai hakikat pengetahuan. Pertama, realisme, yaitu paham yang menyakini bahwa pengetahuan merupakan gambaran atau copy yang sebenarnya dari apa yang ada di dalam alam nyata; kedua, idealisme, teori ini pada dasarnya mengkritik teori yang pertama. Teori ini berpendapat bahwa pengetahuan adalah proses mental dan psikologis yang bersifat subjektif, maka pengetahuan merupakan gambaran subjektif dari realitas. Sementara menurut Harun Nasution, ada dua teori mengenai cara mengetahui, yaitu: pertama, empiris yaitu pengetahuan di peroleh dengan panca indra; kedua, rasionalisme, yaitu pengetahuan di peroleh dengan akal. Panca indra juga di perlukan akant tetapi akal yang menghubungkan data-data satu sama lain sehingga menjadi pengetahuan.

Dari ke empat teori diatas maka dapat disusun menjadi: pertama, realisme empiris, yaitu pengetahuan diperoleh melalui panca indra dan merupakan copy dari kenyataan; kedua, idealisme empiris, yaitu pengetahuan diperoleh dengan panca indra, tetapi tidak menggambarkan ralitas; ketiga, idealisme rasional, yaitu pengetahuan di peroleh dengan akal dan panca indra tetai tidak membari gambaran tentang hakikat; Keempat, realism rasional yaitu pentetahuan diperoleh dengan perantara akal dan panca indra. Data yang di berikan dari panca indra kepada akal, kemudian akal menggunakan prinsip universal. Hasilnya pemikiran itu merupakan copy yang benar tentang hakikat. Kebanaran yang dimaksud adalah kebenaran relative, kebenaran yang dekat dengan hakikat menurut kesanggupan akal. Teori inilah menurut Harun Nasution yang digunakan dalam teori ilmiah. Mengingat alam yang besar, maka tidak semua data dapat terkumpul sehingga yang terkumpul hanya sebagian saja. Dengan demikian pengetahuan yang di peroleh manusia bukanlah pengetahuan yang lengkap dan sempurna. Oleh sebab itu, Harun berkesimpulan bahwa tidak ada teori yang membawa kepada kebenaran atau keyakinan tentang apa yang diketahui benar-benar kenyataan. ${ }^{12}$

\footnotetext{
${ }^{12}$ Nurisman, Pemikiran Filsafat..., hlm. 239-241.
} 
Pengetahuan agama tidak semata-mata berdasarkan kepada wahyu (normatif), tetapi juga mengunakan argument historis, argumen rasional (koherensi) dan pengalaman pribadi. Dengan empat sumber pengetahuan yaitu alQur'an dan hadits, argemen historis, argemen rasional dan pengalaman pribadi, maka pengetahuan agama menjadi shahih dan layak mendapat tempat bagi diskursus di Indonesia.

\section{Paradigma Islam Rasional Sebagai Landasan Teologi Kerukunan}

Teologi pada hakikatnya menyangkut aktivitas mental berupa kesadaran manusia terkait dengan hubungan dengan Tuhan, sesama manusia dan lingkungan yang kemudian terwujud dalam tingkah laku sosial. Teologi bukan semata hanya hubungan vertikal manusia dengan Tuhan, tetapi juga melibatkan hubungan yang horizontal antar sesama manusia dan lingkungan yang dilandasi pada ajaran agama. Oleh karena itu teologi senantiasa memiliki implikasi sosiologis. Terlebih lagi dalam konteks kehidupan pluralitas-multikulural, maka dibutuhkan pendekatan yang kompatibel dalam mamahami agama. Dengan pendekatan seperti ini diharapkan akan lahir paradigma keberagamaan yang inklusif.

Islam Rasional merupakan grand concept yang ditawarkan oleh Harun Nasution atas kprihatinannya terhadap kondisi umat Islam (sebagaimana yang telah dijelaskan pada bagian “beberapa kegelisahan akademik"). Islam rasional diharapkan mampu untuk memperdayakan Islam-tidak menutup kemungkinan juga terhadap agama-agama lain—di Indonesia sebagai pencerahan pemikiran yang selama ini terkungkung oleh dogmatisme pemikiran yang sempit, rigit, serta klaimklaim kebenaran suatu kelompok. Sikap keberagamaan yang seperti ini biasa disebut dengan fundamentalisme reduksionitik yang memiliki keyakinan terhadap kesempurnaan agama sendiri, maka tidak perlu ada pembongkaran dan penyesuaian dengan realitas zaman, tetapi perkembagan zaman yang harus tunduk dengan budaya dan system nilai par-excellence. Hal inilah yang kemudian dikenal sebagai struktur fundamental pola berfikir keagamaan deduktif, yaitu 
kecenderungan pemeluk agama dalam menafsirkan dan mengaktualisasikan kitab sucinya secara tekstual-skriptualis. Konsekuensi dari keberagamaan dan pola pikir deduktif-tekstualistik-skriptualistik (meminjam istilah Amin Abdullah) adalah berkurangnya kepekaan dan ketajaman dalam mencermati fenomena alam, budaya, dan sosial kemasyarakatan yang selalu berubah dan bergerak cepat sehingga memberikan dampak langsung pada isu-isu keagamaan serta format pengalaman beragama di era global ini. ${ }^{13}$

Pembaharuan Islam yang ditawarkan oleh Harun Nasution bukan hanya terletak pada upaya untuk membangkitkan kembali kejayaan umat Islam tetapi mendorong agar umat mampu menjawab dan merespon perubahan sosial. Beliau mengidentifikasikan masalah yang dihadapi oleh umat Islam yaitu telah terjadi reduksi dan distorsi fundamental terhadap ajaran Islam. Sehingga umat Islam lemah dalam mengelolah kebhinekaan. Akibat lain dari terdistorsinya ajaran Islam ialah salah dalam memahami ajaran Islam yang sebenarnya fleksibel, lentur dan dinamis serta memiliki ruang berubah menjadi statis, sempit, fanatik dan banyak konflik serta truth claim. Inilah alasan mengapa ia ingin mengubah pandangan yang fatalistik dan tradisional ini dengan pandangan yang lebih dinamis rasional dan modern. ${ }^{14}$ Tujuan akhir yang di cita-citakan Harun Nasution dalam Islam rasional ialah umat Islam harus berubah dari statis-pasif ke dinamis-proaktif-agresif.

Meskipun fokus kajian pemikirannya lebih banyak diarahkan kepada bidang-bidang ilmu, seperti: ilmu kalam, falsafah dan tasawuf, yang kemudian beliau kembangkan pada ruang akademisi yaitu perguruan tinggi. Hal ini dapat dilihat dari karya-karya beliau yang lebih banyak mengusung ide-ide pemikiran pembaharuan atau modernisasi Islam, filsafat, kalam maupun tasawuf. Dalam hal kaitannya dengan “teologi kerukunan”, pemikiran Islam rasional Harun Nasution juga memiliki relevansi bagi terbentuknya sebuah kerukunan yang berpegang pada tali agama. Meskipun tidak ada kata-kata “jargon” khusus untuk menggambarkan buah

\footnotetext{
Haqqul Yaqin, agama dan kekerasan dalam tradisi demokrasi di Indonesia, (Yogyakarta: eLSAQ Press, 2009) hal. 29-31. hlm. 70

${ }^{14}$ Harun Nasution, Muhammad Abduh dan Teologi Rasional Mu'tazilah, (Jakarta: UI press, 1987),
} 
pemikiran Harun Nasution tentang teologi kerukunan. Lain halnya dengan tokohtokoh yang memang fokus pemikirannya terkonsenterasi pada persoalan kerukunan, mereka tentunya memiliki "kata jargon" khusus sebagai prinsip dalam rangka membumikan kerukunan, misalkan; Mukti Ali dengan jargon agree disagreement; Said Agil Husin Al-Munawar "bottom up” yang lebih diarahkan pada perwjudan rasa kemanusiaan dengan kebijakan "pengembangan wawasan multikultural"; Gus Dur yang konsen pada masalah plaralisme, serta tokoh-tokoh lainnya. Namun, bukan berarti buah pemikiran Harun Nasution tidak memberi kontribusi terhadap persoalan kerukunan.

Fungsi dan tujuan Islam rasional yang ditawarkan oleh Harun Nasution adalah untuk menghilangkan kesangsian dan menetapkan kepercayaan Islam secara kokoh. Pemahaman Islam rasional juga dinilai mampu untuk menampilkan Islam dari berbagai ragam (pluralistik). Dengan demikian, untuk menarik relevansi pemikrian Islam rasional Harun Nasution dengan teologi kerukunan maka dapat dijabarkan diantarannya:

\section{Menjunjung asas prikemakhlukan dan prikemanusiaan}

Ajaran agama Islam—tidak menutup kemungkinan juga pada agama nonIslam-memiliki ajaran yang terpenting yaitu tawhid atau paham kemahaesaan Tuhan. Kerena kepercayaan kepada Tuhan yang maha esa mempunyai efek untuk melahirkan sikap kemanusiaan dan kemakhlukan. Sehingga manusia harus menyadari bahwa sesungguhnya setiap manusia itu adalah bersaudara. Perbedaan agama, ras, bahasa, adat, bangsa, warna kulit dan sebagainya justru mendorong kita sebagai manusia untuk saling mengenal, menghargai dan saling belajar antara satu dengan yang lain sehingga perdamaian dapat tercapai. Ajaran tauhid merupakan filsafat yang mendasari perikemanusiaan dan lebih luas lagi perikemakhlukan. Inilah aspek penting mamahami agama secara rasional. ${ }^{15}$

\section{Membangun sikap toleransi dan keberagamaan Inklusif}

\footnotetext{
${ }^{15}$ Harun Nasution, Prikemakhlukan dan Prikemanusiaan, dalam Saiful Muzani (ed), Islam Rasional: Gagasan dan Pemikiran Prof. Dr. Harun Nasution, (Mizan, Bandung: 1998), hal, 211
} 
Di tengah maraknya aksi-aksi kekerasan, dishamorinis, bahkan konflik yang mengatasnamakan agama, maka tawaran Islam rasional yang digagas Harun Nasution merupakan jembatan untuk membangun sikap toleransi, baik sesama kelompok pemeluk agama maupun kelompok agama lain. Landasan untuk membangun toleransi, menurut Harun Nasution, maka setiap penganut agama harus merujuk kepada ajaran-ajaran agama yang dapat melahirkan toleransi. Karena setiap agama tentunya memiliki ajaran-ajaran atau dogma-dogma kebaikan yang menekankan pada toleransi. Disisi lain juga setiap agama berkeyakinan bahwa Tuhan merupakan zat pencipta alam semesta, termasuk manusia. Dengan kesadaran dan keyakinan bahwa manusia berasal dari Tuhan, maka akan timbul persaudaraan sesama manusia sekalipun berbeda keyakinan agama. Sikap persaudaraan ini bisa menjadi landasan bagi lahirnya sikap toleransi. Dengan demikan jiwa toleransi dalam beragama dapat dipupuk melalui usaha-usaha, diantaranya:

- Mencoba melihat kebenaran yang ada dalam agama lain

- Memperkecil perbedaan yang ada di antara agama-agama

- Menonjolkan persamaan-persamaan yang ada dalam agama-agama

- Memupuk rasa persaudaraan se-Tuhan

- Memusatkan pembinaan individu-individu dan masyarakat manusia baik yang menjadi tujauan beragama dari dari semua agama

- Mengutamakan pelaksanaan ajaran-ajaran agama masing-masing yang dapat membawa kepada toleransi beragama

- Menjauhi praktik serang-menyerang antaragama. ${ }^{16}$

Dengan demikian, sikap-sikap tidak toleransi terhadap pemahaman keagamaan atau umat agama lain dapat diminimalisir.

\section{Dialog dan musyarawah antaragama}

Selain pentingnya membangun jiwa toleransi, Harun Nasution juga menggarisbawahi pentingnya musyawarah antaragama. Musyawarah dapat

\footnotetext{
${ }^{16}$ Harun Nasution, Masalah Toleransi beragama, dalam Saiful Muzani (ed), Islam Rasional, hal,
} 
dilakuan melalui wadah-wadah yang dibentuk dan diberi nama. Musyawarah antaragama ini bertujuan untuk memperbaiki hubungan antaragama yang kurang lancar yang diakibatkan oleh konflik-konflik yang terjadi pada masa lampau. Melalui musyarawah ini, selain menetralisir kecurigaan, dendam, dan lain sebagainya juga dapat melahirkan suatu kerjasama. Tentunya lembaga-lembaga atau kerjasama yang dilakukan tidak membahas atau memperdebatkan masalah doktri ajaran masingmasing agama karena memang membahas doktrin agama tidak akan mencapai titik temu, melainkan membahas permasalahan sosial, seperti kenakalan remaja, peran agama dalam memberantas korupsi, narkoba dan masalah sosial lainnya. ${ }^{17}$

Dengan demikian paradigma Islam rasional merupakan salah satu kontruksi pemikiran dalam membangun teologi kerukunan. Memahami agama secara rasional merupakan tuntutan bagi setiap penganut agama apapun agak tidak terjebak pada klaim-klaim yang dapat mendatangkan sikap arogansi, anarkis, streotip terhadap kelompok agama yang berbeda. Karena kenyataannya perbedaan adalah ketetapan Tuhan yang tidak bisa dihindari.

\section{E. Penutup}

Teologi kerukunan merupakan pemahaman keagamaan yang mengharigai terhadap pluralitas-multikultural yang mewujudkan kerukunan hidup dalam masyarakat yang dilandaskan pada nilai-nilai norma dan nilai kemanusiaan dari ajaran agama.

Pemikiran Islam rasional merupakan solusi tawaran pencerahan bagi umat Islam agar mampu menjawab dan merespon gelombang arus moderinsasi sesuai zamannya. Pemahaman yang rasional terhadap ajaran agama akan mendorong dan membuka pintu bagi umat Islam—juga bagi penganut agama lain-agar mampu mengelolah kebhinekaan, menerima perbedaan serta menghindari klaim-klaim kebenaran (truth claim), yang selama ini cenderung memebeda-bedakan, mensistematisasikan, mengolong-golongkan dan mengkotak-kotakkan. Akibatnya

\footnotetext{
${ }^{17}$ Ibid..., hal. 278
} 
stagnansi pemikiran telah mendorong konflik-konflik ideologis antar umat Islam dan bahkan antar penganut agama lain.

Paradigma Islam rasional merupakan landasan etis dalam kehidupan masyarakat modern dalam upaya membangun kerukunan hidup. Memahami agama secara rasional tidak saja terbatas pada agama Islam saja, namun pendekatan rasional dalam memahami agama juga dapat diterapkan pada agama-agama lain. Karena memahami ajaran agama secara rasional memiliki peran yang signifikan dalam upaya membangun kerukunan. Dengan demikian, pemikiran rasional akan menggiring pada pemahaman agama yang fleksibel, lentur dan dinamis. Sehingga umat beragama dapat menemukan makna dalam membangkitkan sikap toleransi, saling menghargai dan mampu berdialog dengan kolompok yang berbeda, perbedaan kelompok mazhab ataupun agama.

\section{Daftar Pustaka}

Ariendonika, Sketsa Sosial Intelektual Harun Nasution, dalam Nurcholish Madjid, dkk, Teologi Islam Rasional: Apresiasi Terhadap Wacana dan Proksis Harun Nasution, Ciputat Press, Jakarta: 2005.

Harun Nasution, Akal dan Wahyu dalam Islam, Jakarta: UI Press, 1986. , Muhammad Abduh dan Teologi Rasional Mu'tazilah, Jakarta: UI press, 1987.

Prikemakhlukan dan Prikemanusiaan, dalam Saiful Muzani (ed), Islam Rasional: Gagasan dan Pemikiran Prof. Dr. Harun Nasution, Mizan, Bandung: 1998.

, Masalah Toleransi beragama, dalam Saiful Muzani (ed), Islam Rasional: Gagasan dan Pemikiran Prof. Dr. Harun Nasution, Mizan, Bandung: 1998.

Haqqul Yaqin, agama dan kekerasan dalam tradisi demokrasi di Indonesia, Yogyakarta: eLSAQ Press, 2009.

Muhaimin (ed), Damai Di Dunia Damai Untuk Semua: Prespektif Berbagai Agama, Jakarta: Badan Litbang dan Diklat Keagamaan Depag, 2004, hal. 16-18

Muhammad Al-Fayyadl, Derrida, Yogyakarta, LKis: 2005.

Ngainun Naim, Teologi Kerukunan: Mencari Titik Temu Dalam Keberagamaan, Yogyakarta: Teras, 2011. 
Nurisman, Pemikiran Filsafat Islam Harun Nasution; Pengembangan Pemikiran Islam di Indonesia, Teras, Yogyakarta: 2005.

Syahrin Harahap, Metodologi Studi Tokoh Pemikiran Islam, Jakarta, Prenada Media Group: 2011.

, Teologi Kerukunan, (Jakarta: Prenda Media Group, 2011

Tim Panitia Penerbitan Buku dan Seminar 70 Tahun Harun Nasution, Refleksi Pembaharuan Pemikiran Islam 70 Tahun Harun Nasution, Lembaga Studi Agama dan Filsafat, Jakarta: 1989. 